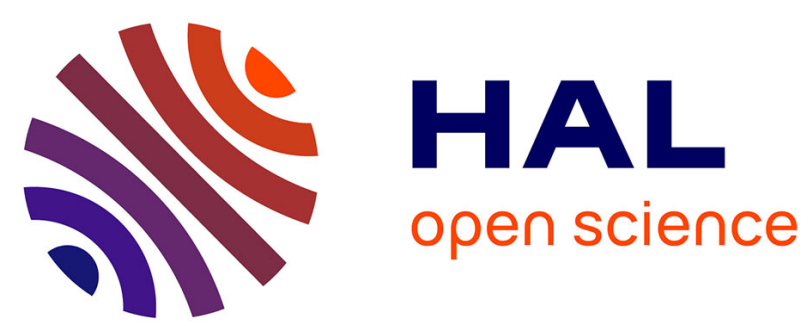

\title{
A Compilation of Silicon and Thirty One Trace Elements Measured in the Natural River Water Reference Material SLRS-4 (NRC-CNRC)
}

Delphine Yeghicheyan, Jean Carignan, Michel Valladon, Martine Bouhnik Le Coz, Florence Le Cornec, Maryse Castrec-Rouelle, Michel Robert, Luc

Aquilina, Emmanuel Aubry, Carine Churlaud, et al.

\section{To cite this version:}

Delphine Yeghicheyan, Jean Carignan, Michel Valladon, Martine Bouhnik Le Coz, Florence Le Cornec, et al.. A Compilation of Silicon and Thirty One Trace Elements Measured in the Natural River Water Reference Material SLRS-4 (NRC-CNRC). Geostandards Newsletter, 2001, 25 (2-3), pp.465474. 10.1111/j.1751-908X.2001.tb00617.x . hal-02167392

\section{HAL Id: hal-02167392 https://hal.science/hal-02167392}

Submitted on 7 Sep 2020

HAL is a multi-disciplinary open access archive for the deposit and dissemination of scientific research documents, whether they are published or not. The documents may come from teaching and research institutions in France or abroad, or from public or private research centers.
L'archive ouverte pluridisciplinaire HAL, est destinée au dépôt et à la diffusion de documents scientifiques de niveau recherche, publiés ou non, émanant des établissements d'enseignement et de recherche français ou étrangers, des laboratoires publics ou privés. 


\title{
A COMPILATION OF SILICIUM AND THIRTY ONE TRACE ELEMENTS
}

\section{MEASURED IN THE NATURAL RIVER WATER STANDARD SLRS-4}

\section{(NRC-CNRC)}

\author{
Delphine Yeghicheyan $^{1}$, Jean Carignan ${ }^{1}$, Michel Valladon ${ }^{2}$, Martine Bouhnik Le $\mathrm{Coz}^{3}$, \\ Florence Le Cornec ${ }^{4}$, Maryse Castrec-Rouelle ${ }^{5}$, Michel Robert ${ }^{6}$, Luc Aquilina $^{3}$, Emmanuel \\ Aubry $^{5}$, Carine Churlaud ${ }^{6}$, Aline Dia $^{3}$, Samuel Deberdt ${ }^{2}$, Bernard Dupré $^{2}$, Rémi Freydier $^{2}$, \\ Gérard Gruau ${ }^{3}$, Odile Hénin ${ }^{3}$, Anne-Marie de Kersabiec ${ }^{5}$, Joël Macé ${ }^{3}$, Luc Marin ${ }^{1}$, Nicole \\ Morin $^{3}$, Patrice Petitjean ${ }^{3}$ and Elodie Serrat ${ }^{3}$
}

1: CNRS-CRPG, Service d'Analyse des Roches et des Minéraux (SARM), 15, rue Notre Dame des Pauvres, BP 20, 54501 Vandoeuvre-lès-Nancy, France. e-mail: yeghi@crpg.cnrs-nancy.fr

2: Laboratoire de Géochimie, 38 rue des Trente-Six-Ponts, 31400 Toulouse Cédex, France. e-mail: valladon@lucid.ups-tls.fr

3: Géosciences Rennes, bd du Général Leclerc 35045 Rennes Cédex, France. e-mail: Martine.Bouhnik-LeCoz@univ-rennes1.fr

4: IRD, Laboratoire des Formations Superficielles, 32 avenue Henri Varagnat, 93143 Bondy Cedex France. email: Florence.le_Cornec@bondy.ird.fr

5: Laboratoire de Géochimie et Métallogénie, Université Pierre et Marie Curie, casier 124, Tour 26/16, 4 Place Jussieu, 75252 Paris Cédex, 05 France. e-mail: Maryse.CASTREC@ @icrp.jussieu.fr

6: Centre Commun d'Analyses, Université de La Rochelle, 5 perspective de l'Océan, 17000 La Rochelle, France.e-mail: mrobert@univ-lr.fr

Keywords : river water reference material, ICP-MS, rare earth elements, trace elements The natural river water standard SLRS-4 (NRC-CNRC) has been routinely analysed for major and trace elements by six French laboratories. Most measurements were done using ICP-MS 
(Inductively Coupled Plasma-Mass Spectrometry). For silicium and thirty one trace elements (rare earth elements, Ag, B, Br, Cs, Ga, Ge, Li, P, Pd, Rb, Se, Th, Ti, Tl, W, Y and Zr), no certified values are assigned by NRC-CNRC. We propose some compilation values and related uncertainties according to the results obtained by the different laboratories.

Mots-clés : standard d'eau de rivière, ICP-MS, terres rares, éléments en traces

Le standard d'eau de rivière SLRS-4 (NRC-CNRC) est analysé régulièrement comme contrôle qualité par six laboratoires français étudiant les éléments majeurs et en traces dans les solutions naturelles. La plupart des mesures sont réalisées par ICP-MS (Inductively Coupled Plasma Mass-Spectrometry). Le silicium et 31 éléments en traces (terres rares, Ag, B, Br, Cs, Ga, Ge, Li, P, Pd, Rb, Se, Th, Ti, Tl, W, Y and Zr) ne sont pas certifiés par NRCCNRC. Nous proposons des valeurs de compilation pour ces éléments ainsi que les incertitudes associées d'après les concentrations moyennes obtenues par chaque laboratoire. 
The natural river water standard SLRS-4 (prepared by the National Research CouncilConseil National de Recherches Canada) is widely used to control routine analysis by geochemists and hydrogeologists. However, some trace elements, useful to trace sources and geochemical processes, have not been assigned certified values. The six participating French laboratories (The Service d'Analyse des Roches et des Minéraux of Nancy, the Geosciences laboratory of Rennes, the Laboratoire de Géochimie of Toulouse, the Laboratoire de Géochimie et Métallogénie of the UPMC Paris, the Laboratoire des Formations Superficielles of IRD Bondy and the Centre Commun d'Analyses of La Rochelle) analysed routinely SLRS4 by ICP-MS, ICP-AES and AAS as a control for the analysis of major and trace elements in water samples. In addition to the certified elements by NRC-CNRC and according to the aim of laboratories, uncertified elements are also measured in the reference water. Nor proficiency tests, neither interlaboratory schemes have been elaborated for this paper. The presented compilation only gathers two years of individual routine results and working values for uncertified elements are proposed.

\section{Instrumentation and statistical treatements}

The equipment of each laboratory is reported in Table 1. Except for the UPMC laboratory, which used AAS and ICP-AES, all the other laboratories used quadrupole ICPMS. The Rennes and Nancy laboratories also performed complementary analyses of Rb and Si using respectively isotope dilution TIMS and spectrophotometry. The instrument operating parameters were similar for all the ICP-MS but the introduction sampling systems, the 
substracted blanks, the acid molarity of the analysed solutions and the calibration methods were specific for each laboratory. A desolvator (High temperature hydraulic High Pressure Nebulizer) is used by the laboratory of Toulouse for some trace elements. This method was described in Jakubowski et al. (1992) and Berndt et al. (1996). The on-line liquid chromatography used by the team of Nancy is described in detail in this volume (Carignan et $a l ., 2001)$. Oxides and doubly charged ions were less than $3 \%$ and the different laboratories have applied oxide and hydroxide interference corrections (Le Cornec et al., 1999; Aries et al., 2000; Bouhnik-Le Coz et al., 2001). Wavelengths without spectral interferences were used by the UPMC Paris laboratory with the optical techniques. Some of these corrections are reported in Table 1.

Calibrations were done using synthetic multi elemental solutions except for B concentration measurements performed in Nancy, for which this laboratory used a mono elemental B standard solution, as described in Rose et al. (2000). Some laboratories corrected the instrumental drift by adding an internal standard to samples such as In (Rennes), In and Re (Toulouse), Tm (IRD Bondy) and Rh (La Rochelle). When no internal standard is used (Nancy and IRD Bondy), the eventual drift is controlled by measuring the standard solution every 4-5 samples. Blanks and acids are consigned in Table 1: blanks are acidified with $\mathrm{HNO}_{3}$ to reach 2 molar for Nancy (Carignan et al., 2001) and 0.1 to 0.5 molar for other laboratories. The Rennes laboratory added $\mathrm{HNO}_{3}$ in samples to reach $\mathrm{pH} 1$ (instead of $\mathrm{pH} 1.6$ reported by NRC-CNRC for SLRS-4) because they observed a more stable signal for all elements in these conditions. Table 2 summarises isotopes and internal standards measured by the different 
teams. When several isotopes were measured, we choose the isotope with the smallest standard deviation after verifying the absence of interferences. For lead, ${ }^{208} \mathrm{~Pb}$ was used for the compilation.

Laboratories have preliminary rejected the outliers by their own methods. Two of them (UPMC Paris, La Rochelle) eliminate values out of the individual mean value \pm 2 sd (standard deviation). The Dixon and Grubbs tests at 95\% confidence level (Miller \& Miller,1993 ; Prichard, 1995; Feinberg, 1996) have been applied by the others. The analysis of variance (ANOVA) calculations (Neuilly and Cetama, 1993) were also performed between the Nancy, Toulouse, Rennes and the IRD Bondy results in order to validate the compilation. Detailed data were not available for the others.

The aim of this paper is not to certified elemental concentrations in SLRS-4, but to document the homogeneity of results obtained from different laboratories, using different techniques, and to eventually propose working values for uncertified elements. The compilation data (mean and standard deviation) were then calculated from the average values of each laboratory without taking into account the different number of results and the individual incertainties (no weight applied). In general, an individual mean was rejected to the compilation when it is out of the overall average \pm twice the compiled standard deviation (95\% of confidence limits). The same calculations were performed for certified elements in order to assess the quality of laboratories analysis. 


\section{Results and discussion}

\section{Certified values}

Table 3 reports average concentrations obtained by the different laboratories for elements having certified concentrations in SLRS-4. The compilation data represent the artithmetic mean calculated from values reported by each laboratory. Except for few ones, most elements fall within the certified confidence limits if we take into account the individual and the compiled incertainties. Uncorrected/corrected polyatomic interferences on $\mathrm{Ca}, \mathrm{Cr}, \mathrm{Fe}$, $\mathrm{K}, \mathrm{Na}, \mathrm{Zn}$ ) or possible contamination for elements like $\mathrm{Cd}$ and $\mathrm{Zn}$ might explain the outliers and some high standard deviations.

Elements like $\mathrm{Co}, \mathrm{Cr}$ and $\mathrm{Fe}$ are known to be easily interfered by $\mathrm{ArO}$ species (Date and Gray, 1989, Reed et al., 1994, May and Wiedmeyer, 1998). The sulfur and ArO species on $\mathrm{Zn}$ might explain the high values obtained by the participants except with the desolvation method. In the case of $\mathrm{Ca}$, the use of both techniques, ICP-MS and ICP-AES confirmed a lower value than that obtained by NRC-CNRC with ICP-AES and FAAS and it should be interesting to re-evaluate the Ca concentration by other laboratories.

Individual laboratories obtained $83 \%$ of values for certified elements within the NRCCNRC confidence limits and $95 \%$ of compiled data fall within these limits. This insures the proficiency of the participating laboratories for results on the other elements and validates our mode of calculations for uncertified elements. 


\section{Uncertified values}

Average concentrations obtained by the laboratories are reported in Tables 4 and 5 .

\section{Rare Earth Elements}

Results for Rare Earth Elements (REEs) are shown in Table 4. For all REEs, the relative standard deviation (rsd) obtained for the compilation values ranges from $3 \%$ to $10 \%$ for concentrations varying between $360 \mathrm{ng} . \mathrm{l}^{-1}$ for Ce to $1.7 \mathrm{ng} . \mathrm{l}^{-1}$ for Tm suggesting a fairly good homogeneity of the results between laboratories and techniques. The rsd values are not correlated with the concentration, the highest values being affected to the middle REEs and $\mathrm{Tm}$. The high standard deviation for Tm is due to the low Tm concentration yielded by Toulouse direct introduction method, which is $20 \%$ lower than the mean obtained by the other laboratories. Higher variations for the middle REEs between laboratories may in part explained by the fact that these elements are interfered by Light REEs (LREEs) and Ba oxides for which the corrections (or no correction) introduce some noise. The low values of Heavy REEs (HREEs), except for $\mathrm{Yb}$ and $\mathrm{Lu}$, reported by Toulouse with its direct introduction method may result from the LREEs corrections applied by this laboratory (Ariès et al., 2000). This is supported by the fact that this laboratory yielded values closer to the compilation by using the desolvation technique, which generate a very low oxide formation. High values for Gd and Dy reported by the IRD Bondy may be explained by the fact that this laboratory for 
these elements applied no oxide corrections. However, Nancy did correct for Gd and obtained similar value and did not correct for Dy and obtained lower value.

The REE patterns normalised to concentrations of the upper crust (Taylor and McLennan, 1985) for each laboratory are reported in Figure 1. The REE patterns display a LREE enrichment relative to the Heavy REEs and an important negative Ce anomaly. The general pattern may reflect the composition of lithologies along the flow path of the river (Brookins, 1989; Verplanck et al., 2001). The Ce anomaly is commonly observed for river waters and is probably due to the redox conditions and the trapping of $\mathrm{Ce}^{\mathrm{IV}}$ by the $\mathrm{Fe}$ and $\mathrm{Mn}$ oxides (Fleet, 1984; Brookins, 1988).

\section{II.b.2 Other elements}

Eighteen other elements having no certified values were analysed. Results are reported in Table 5. Six elements (B, Li, Th, Rb and $\mathrm{Si}$ ) were determined by at least 3 different laboratories or methods (Figure 2). All the available data for B, Li, Th and $\mathrm{Rb}$ were used for the compilation values, including complementary data by ID-TIMS for Rb. Figure 2 shows that results from the different laboratories are within error except for Li (Nancy). Nancy and Toulouse (desolvator) reported the two extrem Li concentrations of $0.444 \pm 0.013 \mu \mathrm{g} . \mathrm{l}^{-1}$ and $0.615 \pm 0.027 \mu \mathrm{g} . \mathrm{l}^{-1}$ respectively and La Rochelle reported intermediate concentrations of $0.504 \pm 0.026 \mu \mathrm{g} . \mathrm{l}^{-1}$. These results might be explained by some bias in the calibration between laboratories. Si concentration was measured by two techniques : ICP-MS and spectrophotometry (Table 5). Values obtained by spectrophotometry from Rennes and Nancy are rather similar. The ICP-MS value from Rennes is in agreement with those obtained by 
spectrophotometry whereas Si concentrations determined by ICP-MS from Toulouse are lower and less reproducible (rsd of $\sim 20 \%$ compared to $\sim 1 \%$ obtained by spectrophotometry). The Si value measured in SLRS-4 is closed to the estimated determination limit of the ICPMS method for this element. The high Si background contribution observed by the Toulouse team in that concentration range certainly leads to inaccurate correction and explains the heterogeneity of the results. Therefore, we decided to exclude Si values reported by Toulouse from the compilation calculations.

Three other trace elements (Ti, Tl, Y) were analysed by two laboratories (Table 5). Results for these elements are, within error, identical between the two laboratories.

All other trace elements reported in Table 5 (Ag, Br, Cs, Ga, Ge, W, Zr, P, Pd, Se) were analysed only by the Toulouse laboratory. In all cases, when these elements were analysed by the two nebulisation systems, an identical concentration, within error, was obtained (Table 5).

\section{Conclusion}

We report a compilation of concentrations for uncertified elements in the natural river water standard SLRS-4 (NRC-CNRC) from two years of routine analysis in six different French laboratories. These reported coherent results for REE concentrations, with rsd for the compilation values ranging from $3 \%$ to $10 \%$. Eight elements ( $\mathrm{Li}$, Th, $\mathrm{Rb}, \mathrm{B}, \mathrm{Ti}, \mathrm{Tl}, \mathrm{Y}, \mathrm{Si}$ ) analysed at least by two laboratories yielded compilation values having rsd ranging from 3\% 
to $16 \%$. Fourteen other trace elements concentrations were reported, but with a more restrictive number of results. 


\section{References}

Aries S., Valladon M., Polvé M. and Dupré B. (2000)

A routine method for oxide and hydroxide interference corrections in ICP-MS chemical analysis of environmental and geological samples. Geostandards Newsletter 24,1, 19-31.

Berndt T H. and Yanez J.(1996)

High temperature hydraulic high-pressure nebulization: a recent nebulization principle for sample introduction. Journal of Analytical Atomic Spectrometry, 11, 703-712.

Bouhnik-Le Coz M., Petitjean P., Serrat E. and Gruau G. (2001)

Validation d'un protocole permmettant le dosage simultané des cations majeurs et traces dans les eaux douces naturelles par ICP-MS. Les Cahiers Techniques, Ed. Géosciences Rennes, 1, $82 \mathrm{pp}$.

Brookins D.G. (1988)

Eh-pH Diagrams for Geochemists. Springer-Verlag Pubs., New-York, 176 pp.

Brookins D.G. (1989)

Aqueous geochemistry of rare earth elements. In P. Ribbe Ed., Geochemisrty and mineralogy of Rare Earth Elements,, Mineralogical Society of America, Reviews in Mineralogy 21, 201223.

Carignan J., Hild P., Mevelle G., Morel J. and Yeghicheyan D. (2001)

Routine analysis of trace elements in geological samples using flow-injection and lowpressure on-line liquid chromatography ICP-MS: a study of geostandards BR, DR-N, UB-N, ANG and GH, Geostandards Newsletter, in this issue. 
Date A.R. and Gray A.L. (1989)

Applications of inductively coupled plasma mass spectrometry. Blackie Ed., New York, 254 pp.

Feinberg M. (1996)

La validation des méthodes d'analyse : une approche chimiométrique de l'assurance qualité au laboratoire. Masson, Paris, 397 pp.

Fleet A.J. (1984)

Aqueous and sedimentary geochemistry of rare earth elements. In: P. Henderson Ed., Rare

Earth Elements Geochemistry. Elsevier Science Pubs, Amsterdam, 343-373.

Jakubowski N., Feldmann I. and Stuewert D.(1992)

Analytical improvement of pneumatic nebulization in ICP-MS by desolvatation.

Spectrochimica Acta 47B,1,107-118.

Le Cornec F., Gerard M. and Giffard I. (1999)

Preconcentration and determination by ICP-MS of rare earth elements and some metal ions in water samples. 99 European Winter Conference on Plasma Spectrochemistry (Pau), abstract volume, 133.

May T.W. and Wiedmeyer R.H. (1998)

A table of polyatomic interferences in ICP-MS. Atomic Spectroscopy 19, 150-155.

Miller J.C. and Miller J.N. (1993) 
Statistics for analytical chemistry. $3^{\text {rd }}$ ed., Ellis Horwood PTR Prentice Hall, New York, 233 pp.

Neuilly M. and Cetama (1993)

Modélisation et estimation des erreurs de mesures. Lavoisier Ed., Paris, 644 pp.

Prichard F.E., Crosby N.T., Day J.A., Hardcastle W.A., Holcombe D.G. and Treble R.D. (1995)

Quality in the analytical chemistry laboratory. In Analytical Chemistry by Open Learning. John Wiley and Sons Ed., 307 pp.

Reed N.M., Cairns R.O. and Hutton R.C. (1994)

Characterization of polyatomic ion interferences in inductively coupled plasma mass spectrometry using a high resolution mass spectrometer. Journal of Analytical Atomic Spectrometry 9, 881-896.

Rose E.F., Carignan J. and Chaussidon M. (2000)

Transfert of atmospheric Boron from oceans to continents : an investigation using precipitation waters and epiphytic lichens. AGU and Geochemical Society publication, G3 1, $15 \mathrm{pp}$.

Taylor S.R. and McLennan S.M. (1985)

The continental crust : its composition and evolution. Blackwell, Oxford, 460pp.

Verplanck P.L., Antweiler R.C., Nordstrom D.K. and Taylor H.E. (2001)

Standard reference water samples for rare earth element determinations. Applied

Geochemistry 16, 231-244. 


\section{Figure caption}

Figure 1: Upper crust-normalized REEs patterns of the river water standard SLRS-4 obtained by the different laboratories. $n=$ number of results. Upper crust data from Taylor and McLennan (1985).

Figure 2: Average concentrations of B (a), Li (b), Si (c), Th (d) and Rb (e) determined by each participating laboratory in the river water standard SLRS-4. The compilation values are displayed in the legend. Full line : compilation value. Shaded area : standard deviation of the compilation value. desolv.: desolvator. spectrophoto.: spectrophotometry. ID-TIMS : isotope dilution-TIMS. 


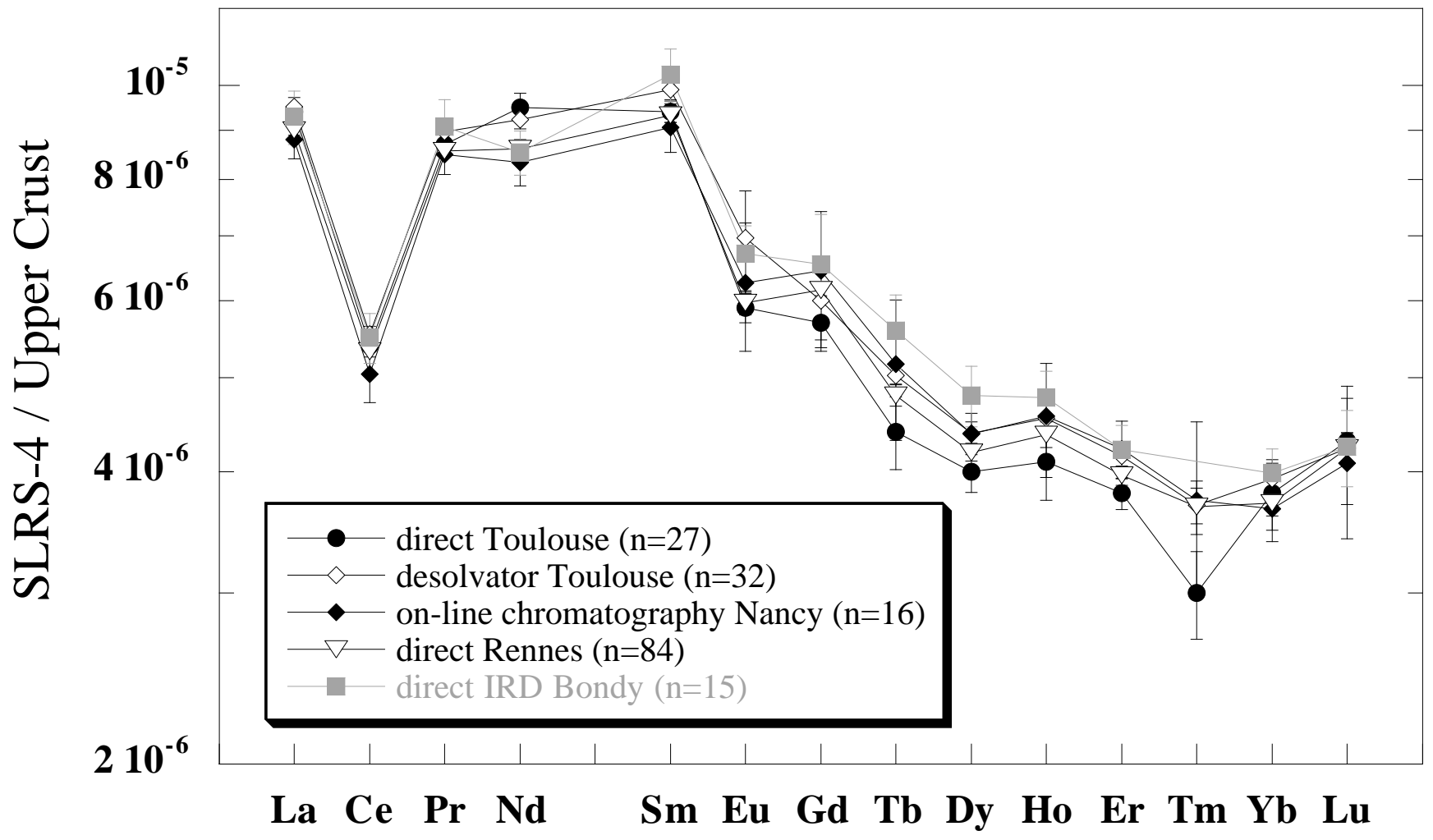



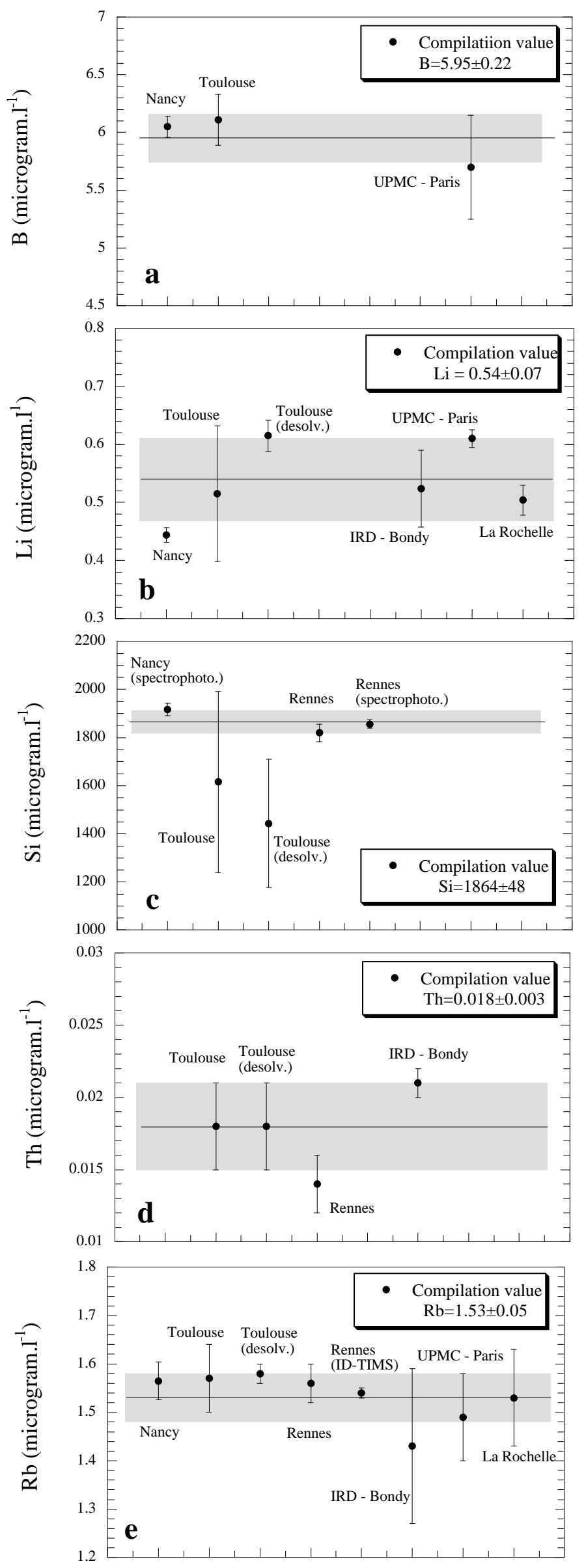
Table 1: Instrumentation and procedures of the participating laboratories.

\begin{tabular}{|c|c|c|c|c|c|c|c|c|}
\hline Laboratory & \multicolumn{2}{|c|}{ Instrument } & \multicolumn{2}{|c|}{ Methods and introduction systems } & \multirow{2}{*}{$\begin{array}{c}\text { Blank } \\
\text { distilled water }\end{array}$} & \multirow{2}{*}{$\begin{array}{c}\text { Acid medium } \\
\mathrm{HNO}_{3} \text { purified by sub-boiling } \\
\text { distillation } \\
5 \%\end{array}$} & \multirow{2}{*}{$\begin{array}{c}\text { Calibration } \\
\begin{array}{c}\text { multi elemental } \\
\text { mono elemental for B }\end{array} \\
10 \mu \mathrm{g} . \mathrm{I}^{-1} \\
0.5 \mu \mathrm{g} . \mathrm{I}^{-1} \text { for REEs }\end{array}$} & \multirow[t]{2}{*}{ Interferences corrections } \\
\hline \multirow[t]{2}{*}{ Nancy } & ICP-MS & Perkin Elmer ELAN 6000 & \begin{tabular}{|c|} 
direct (all elements \\
except REE) \\
Meinhard nebulizer and \\
Scott spray chamber
\end{tabular} & $\begin{array}{l}\text { on-line chromatography } \\
\text { (REE) } \\
2 \text { electrovalves with a } \\
\text { microcolumn connected to a } \\
\text { Meinhard nebulizer and a } \\
\text { Scott spray chamber }\end{array}$ & & & & \\
\hline & Spectrophotometry & Beckman DU 62 & \multicolumn{2}{|c|}{ direct $(\mathbf{S i})$} & $\begin{array}{l}\text { De-ionised water } \\
\text { purified with a UHQ } \\
\text { (Elga) system }\end{array}$ & - & $\begin{array}{c}0,0.25,0.62,1.25 \mathrm{mg} \cdot .^{-1} \\
(5 \mathrm{~mL} \text { of sample in } 10 \mathrm{~mL})\end{array}$ & - \\
\hline Toulouse & ICP-MS & Perkin Elmer ELAN 6000 & $\begin{array}{l}\text { direct (all elements) } \\
\text { Cross-flow nebulizer and } \\
\text { Scott spray chamber }\end{array}$ & $\begin{array}{l}\text { HHPN* desolvator } \\
\text { (all elements) } \\
\text { Meinhard nebulizer and } \\
\text { cyclonic spray chamber }\end{array}$ & $\begin{array}{l}\text { De-ionised water } \\
\text { purified with a MilliQ } \\
\text { (Millipore) system }\end{array}$ & $\begin{array}{l}\mathrm{HNO}_{3} \text { doubly purified by sub- } \\
\text { boiling distillation } \\
2 \% \text { and reacidificication at } 2 \% \\
\text { of the SLRS- } 4 \text { water }\end{array}$ & $\begin{array}{l}\text { multi elemental with internal } \\
\text { standards In, Re } \\
\begin{array}{c}10,50 \mu \mathrm{g} \cdot \mathrm{I}^{-1} \\
\left(\mathrm{In}=\operatorname{Re}=10 \mu \mathrm{g} \cdot \mathrm{I}^{-1}\right)\end{array}\end{array}$ & Aries et al. (2000) \\
\hline \multirow{3}{*}{ Rennes } & ICP-MS & Hewlett Packard 4500 & \multicolumn{2}{|c|}{ direct (all elements) } & $\begin{array}{l}\text { De-ionised water } \\
\text { purified with a MilliQ } \\
\text { (Millipore) system } \\
\text { internal standard In }\end{array}$ & $\begin{array}{l}\mathrm{HNO}_{3} \text { purified by sub-boiling } \\
\text { distillation } \\
2 \% \text { and reacidification at } 2 \% \\
\text { of the SLRS-4 water }\end{array}$ & $\begin{array}{l}\text { multi elemental with internal } \\
\text { standard In }\end{array}$ & Bouhnik-le Coz et al. (2001) \\
\hline & Spectrophotometry & Biotek - Uvikon XS & \multicolumn{2}{|c|}{ direct $(\mathbf{S i})$} & $\begin{array}{c}\text { De-ionised water } \\
\text { purified with a MilliQ } \\
\text { (Millipore) system }\end{array}$ & - & $\mathrm{Si}=5,10,20,30,60 \mathrm{mg} \cdot \mathrm{l}^{-1}$ & - \\
\hline & Mass Spectrometry & Finnigan MAT 262 & \multicolumn{2}{|c|}{ isotopic dilution (Rb) } & - & - & $\begin{array}{c}\text { Spikes } \\
\begin{array}{l}{ }^{84} \mathrm{Sr}=0.1184 \mu \mathrm{g} \cdot \mathrm{g}^{-1}(99,8 \%) \\
{ }^{87} \mathrm{Rb}=5.5750 \mu \mathrm{g} \cdot \mathrm{g}^{-1}(98 \%)\end{array}\end{array}$ & - \\
\hline IRD Bondy & ICP-MS & Varian UltraMass 700 & \multicolumn{2}{|c|}{$\begin{array}{c}\text { direct or after off-line chromatography (all elements) } \\
\begin{array}{c}\text { V-groove nebulizer or ultrasonic nebulizer and Sturman- } \\
\text { masters cyclonic spray chamber }\end{array}\end{array}$} & $\begin{array}{l}\text { De-ionised water } \\
\text { purified with a MilliQ } \\
\text { (Millipore) system }\end{array}$ & $\mathrm{HNO}_{3}$ & \begin{tabular}{|} 
multi elemental with or without \\
internal standard Tm \\
\\
five standards from 0.005 to $100 \mu \mathrm{gg} .1$ \\
$\quad$ according to the concentration \\
range of the element \\
$\quad=1 \mu \mathrm{g} . \mathrm{I}^{-1}$ )
\end{tabular} & $\begin{array}{c}{ }^{51} \mathrm{~V}=-3.1081 *{ }^{53} ?+0.3524 * 2 \mathrm{Cr} \\
{ }^{75} \mathrm{As}=-3.1278 * 77 ?+1.0177 *{ }^{* 7} \mathrm{Se} \\
{ }^{87} \mathrm{Sr}=-0,3856 * *^{85} \mathrm{Rb} \\
{ }^{86} \mathrm{Sr}=-1,504 *{ }^{* 8} \mathrm{Kr} \\
{ }^{138} \mathrm{Ba}= \\
-0,0009008 * \mathrm{La}-0,003394 *{ }^{140} \mathrm{Ce}\end{array}$ \\
\hline \multirow[t]{2}{*}{ UPMC Paris } & ICP-AES & Jobin Yvon 238 sequential & $\begin{array}{r}\text { direct }(\mathbf{M g}, \mathbf{C} \\
\text { Meinhard nebulizer and } \\
\text { radial pla }\end{array}$ & $\begin{array}{l}\text { a, } \mathbf{S r}, \mathbf{F e}, \mathbf{B a}, \mathbf{B}) \\
\text { yclonic spray chamber with } \\
\text { sma viewing }\end{array}$ & \multirow[t]{2}{*}{$\begin{array}{l}\text { De-ionised water } \\
\text { purified with a MilliQ } \\
\text { (Millipore) system }\end{array}$} & \multirow[t]{2}{*}{$\mathrm{HNO}_{3}$} & \begin{tabular}{|c|} 
multi elemental \\
two or four standards from 0 to 10 \\
mg. $\mathrm{I}^{-1}$ according to the concentration \\
range of the element
\end{tabular} & \multirow[t]{2}{*}{ - } \\
\hline & AAS & $\begin{array}{l}\text { Hitachi Z5000 and TJA } \\
\text { Solutions Solaar989QZ }\end{array}$ & $\operatorname{direct}(M$ & $, \mathbf{C u}, \mathbf{L i}, \mathbf{R b})$ & & & multi elemental & \\
\hline La Rochelle & ICP-MS & Varian UltraMass 700 & \multicolumn{2}{|c|}{$\begin{array}{c}\text { V-groove nebulizer and Sturman-masters cyclonic spray } \\
\text { chamber }\end{array}$} & $\begin{array}{l}\text { De-ionised water } \\
\text { purified with a MilliQ } \\
\text { (Millipore) system }\end{array}$ & $\mathrm{HNO}_{3}$ & \begin{tabular}{|c|} 
multi elemental with internal \\
standard Rh \\
\\
seven standards from 0.01 to $10 \mu \mathrm{g} . \mathrm{I}$ \\
${ }^{ }$according to the concentration \\
range of the element \\
$\left(\mathrm{Rh}=0.1\right.$ or $\left.1 \mu \mathrm{g} . \mathrm{I}^{-1}\right)$
\end{tabular} & $\begin{aligned}{ }^{51} \mathrm{~V}= & -3.1081 *{ }^{53} ?+0.3524 *{ }^{52} \mathrm{Cr} \\
& =-3.1278^{* 77} ?+1.01777^{* 78} \mathrm{Se}\end{aligned}$ \\
\hline
\end{tabular}


Table 2: Isotopes used for ICP-MS, wavelenght used for ICP-AES and AAS by the participating laboratories. Internal standards isotopes are in bold faces.

\begin{tabular}{|c|c|c|c|c|c|c|}
\hline & & & Isotopes & & & wavelenght $(\mathrm{nm})$ \\
\hline & Nancy & Toulouse & Rennes & IRD Bondy & La Rochelle & UPMC Paris \\
\hline$\overline{\mathrm{Ag}}$ & & 107 & & & & \\
\hline Al & 27 & 27 & 27 & & 27 & \\
\hline As & 75 & 75 & & & 75 & \\
\hline B & 10,11 & 11 & & & & 249.773 \\
\hline $\mathbf{B a}$ & 138 & 137,138 & 137 & 137,138 & 137 & 455.403 \\
\hline $\mathbf{B e}$ & & & & & 9 & \\
\hline $\mathbf{B r}$ & & 35 & & & & \\
\hline $\mathbf{C a}$ & & 43 & 44 & & & 422.673 \\
\hline Cd & 114 & 114 & 111 & & 111 & \\
\hline $\mathrm{Ce}$ & 140 & 140 & 140 & 140 & & \\
\hline Co & 59 & 59 & & 59 & 59 & \\
\hline $\mathrm{Cr}$ & 53 & 52,53 & 53 & 52 & 52 & \\
\hline $\mathbf{C u}$ & 63 & 63,65 & 65 & 65 & 65 & 324.8 \\
\hline Cs & & 133 & & & & \\
\hline Dy & 164 & 162,163 & 163 & 163 & & \\
\hline Er & 166 & 166,167 & 166 & 166 & & \\
\hline $\mathbf{E u}$ & 153 & 151,153 & 153 & 151,153 & & \\
\hline $\mathbf{F e}$ & & 57 & 57 & & & 238.21 \\
\hline Ga & & 69,71 & & & & \\
\hline Gd & 158 & $156,157,158$ & 158 & 157 & & \\
\hline Ge & & 70,74 & & & & \\
\hline Ho & 165 & 165 & 165 & 165 & & \\
\hline In & & 115 & 115 & & & \\
\hline $\mathbf{K}$ & & 39 & 39 & & & \\
\hline La & 139 & 139 & 139 & 139 & & \\
\hline $\mathbf{L i}$ & 7 & 7 & & 7 & 7 & 670.8 \\
\hline Lu & 175 & 175 & 175 & 175 & & \\
\hline Mg & & 24 & 24 & & & 280.27 \\
\hline Mn & 55 & 55 & 55 & 55 & 55 & 280.1 \\
\hline Mo & & 95 & & 95,98 & & \\
\hline $\mathbf{N a}$ & & 23 & 23 & & & \\
\hline Nd & 142 & 143,146 & 146 & 146 & & \\
\hline $\mathbf{N i}$ & & 60,62 & & 60 & 60 & \\
\hline $\mathbf{P}$ & & 31 & & & & \\
\hline $\mathbf{P b}$ & 208 & $204,206,207,208$ & $206,207,208$ & & & \\
\hline Pd & & 105 & & & & \\
\hline Pr & 141 & 141 & 141 & 141 & & \\
\hline $\mathbf{R b}$ & 85 & 85 & 85 & 85 & 85 & 780 \\
\hline $\mathbf{R e}$ & & 187 & & & & \\
\hline $\mathbf{R h}$ & & & & & 103 & \\
\hline Sb & & 121 & & & & \\
\hline Se & & 77,78 & & & & \\
\hline Si & & 29 & 29 & & & \\
\hline Sm & 152 & 147,152 & 147 & 147 & & \\
\hline $\mathrm{Sr}$ & 88 & 86,88 & 88 & 86,87 & 88 & 421.552 \\
\hline $\mathbf{T b}$ & 159 & 159 & 159 & 159 & & \\
\hline Th & & 232 & 232 & & & \\
\hline $\mathbf{T i}$ & & 47,49 & & 47 & & \\
\hline $\mathbf{T l}$ & 205 & 205 & & & & \\
\hline Tm & 169 & 169 & 169 & 169 & & \\
\hline $\mathbf{U}$ & 238 & 238 & 238 & 238 & 238 & \\
\hline $\mathbf{V}$ & 51 & 51 & & 51 & 51 & \\
\hline $\mathbf{W}$ & & 184 & & & & \\
\hline $\mathbf{Y}$ & & 89 & & & & \\
\hline $\mathbf{Y b}$ & 174 & 172,174 & 174 & 172 & & \\
\hline Zn & 66 & 66,68 & 66 & 66 & & \\
\hline $\mathbf{Z r}$ & & 90 & & & & \\
\hline
\end{tabular}


Table 3 : Average concentration values $\left(\mu \mathrm{g} . \mathrm{I}^{-1}\right)$, standard deviation and relative standard deviation of certified elements in the river water standard SLRS-4.

\begin{tabular}{|c|c|c|c|c|c|c|c|c|c|c|c|c|c|c|c|c|c|c|c|c|c|c|c|c|c|c|c|c|}
\hline \multicolumn{4}{|c|}{ certified values } & \multicolumn{3}{|c|}{ Nancy direct $(n=25)$} & \multicolumn{3}{|c|}{ Toulouse direct $(\mathrm{n}=\mathbf{2 6})$} & \multicolumn{3}{|c|}{ Toulouse desolvator $(\mathbf{n}=\mathbf{3 2})$} & \multicolumn{3}{|c|}{ Rennes direct $(n=84)$} & \multicolumn{3}{|c|}{ IRD Bondy (n=14) } & \multicolumn{3}{|c|}{ UPMC Paris $(n=10)$} & \multicolumn{3}{|c|}{ La Rochelle (n=15) } & \multicolumn{4}{|c|}{ COMPILATION } \\
\hline Element & $\mu \mathrm{g} . \mathrm{l}^{1}$ & CLs & $\begin{array}{l}\text { rCLs } \\
(\%)\end{array}$ & average & sd & $\operatorname{rsd}(\%)$ & average & sd & $\operatorname{rsd}(\%)$ & average & sd & $\operatorname{rsd}(\%)$ & average & sd & $\operatorname{rsd}(\%)$ & average & sd & $\operatorname{rsd}(\%)$ & average & sd & $\operatorname{rsd}(\%)$ & average & sd & $\operatorname{rsd}(\%)$ & Element & average & sd & $\operatorname{rsd}(\%)$ \\
\hline $\mathbf{A l}$ & 54 & 4 & 7.4 & 52.0 & 3.0 & 5.8 & 51.3 & 3.1 & 6.1 & 55.7 & 1.4 & 2.6 & 52.8 & 1.6 & 3.0 & - & - & - & - & - & - & 51.1 & 3.1 & 6.1 & Al & 53 & 2 & 3.6 \\
\hline As & 0.68 & 0.06 & 8.8 & 0.68 & 0.09 & 12.8 & 0.75 & 0.04 & 5.6 & 0.72 & 0.02 & 2.8 & - & - & - & - & - & - & - & - & - & 0.67 & 0.06 & 8.3 & As & 0.70 & 0.04 & 5.5 \\
\hline Ba & 12.2 & 0.6 & 4.9 & 13.1 & 0.5 & 4.2 & 12.7 & 0.4 & 3.3 & 13.2 & 0.3 & 2.2 & 12.6 & 0.1 & 0.7 & 12.0 & 0.7 & 6.1 & 12.8 & 0.3 & 2.3 & 11.8 & 0.5 & 4.3 & Ba & 12.6 & 0.52 & 4.1 \\
\hline $\mathrm{Be}$ & 0.007 & 0.002 & 28.6 & - & - & - & - & - & - & - & - & - & - & - & - & - & - & - & - & - & - & 0.008 & 0.002 & 28.4 & Be & 0.008 & 0.002 & 28.4 \\
\hline $\mathbf{C a}$ & 6200 & 200 & 3.2 & - & - & - & 4267 & 253 & 5.9 & - & - & - & 5859 & 168 & 2.9 & - & - & - & 5630 & 170 & 3.0 & - & - & - & $\mathrm{Ca}$ & 5252 & 861 & 16.4 \\
\hline Cd & 0.012 & 0.002 & 16.7 & 0.011 & 0.001 & 4.5 & 0.013 & 0.002 & 15.9 & 0.013 & 0.002 & 13.2 & 0.015 & 0.001 & 8.8 & - & - & - & - & - & - & 0.017 & 0.007 & 42.8 & Cd & 0.014 & 0.002 & 17.8 \\
\hline Co & 0.033 & 0.006 & 18.2 & 0.046 & 0.007 & 14.3 & 0.053 & 0.017 & 32.8 & 0.035 & 0.001 & 2.3 & - & - & - & 0.046 & 0.006 & 13.9 & - & - & - & 0.057 & 0.015 & 26.1 & Co & 0.048 & 0.008 & 17.9 \\
\hline $\mathrm{Cr}$ & 0.33 & 0.02 & 6.1 & 0.40 & 0.03 & 6.6 & 0.34 & 0.14 & 41.4 & 0.42 & 0.05 & 12.8 & 0.31 & 0.01 & 4.4 & 0.41 & 0.08 & 19.1 & - & - & - & 0.32 & 0.05 & 16.9 & $\mathrm{Cr}$ & 0.37 & 0.05 & 12.5 \\
\hline $\mathrm{Cu}$ & 1.81 & 0.08 & 4.4 & 2.0 & 0.2 & 9.3 & 1.87 & 0.09 & 4.7 & 2.45 & 0.72 & 29.2 & 1.87 & 0.06 & 3.1 & 1.85 & 0.12 & 6.7 & 1.77 & 0.07 & 3.7 & 1.75 & 0.10 & 5.8 & $\mathrm{Cu}$ & 1.93 & 0.24 & 12.4 \\
\hline $\mathrm{Fe}$ & 103 & 5 & 4.9 & - & - & & 116 & 8 & 6.8 & 109 & 3 & 2.4 & 107 & 6 & 5.3 & - & - & - & 100 & 2 & 1.5 & - & - & - & $\mathrm{Fe}$ & 108 & 7 & 6.1 \\
\hline $\mathbf{K}$ & 680 & 20 & 2.9 & - & - & - & 671 & 89 & 13.3 & 597 & 18 & 2.9 & 603 & 15 & 2.4 & - & - & - & - & - & - & - & - & - & $\mathbf{K}$ & 624 & 41 & 6.6 \\
\hline Mg & 1600 & 100 & 6.3 & - & - & - & 1695 & 91 & 5.4 & 1658 & 77 & 4.6 & 1593 & 38 & 2.4 & - & - & - & 1550 & 45 & 2.9 & - & - & - & Mg & 1624 & 65 & 4.0 \\
\hline Mn & 3.37 & 0.18 & 5.3 & 3.44 & 0.15 & 4.2 & 3.39 & 0.14 & 4.2 & 3.53 & 0.08 & 2.3 & 3.37 & 0.07 & 2.0 & 3.25 & 0.39 & 11.9 & 3.46 & 0.12 & 3.5 & 3.18 & 0.15 & 4.7 & Mn & 3.37 & 0.12 & 3.7 \\
\hline Mo & 0.21 & 0.02 & 9.5 & - & - & - & 0.24 & 0.07 & 28.4 & 0.18 & 0.02 & 10.1 & - & - & - & 0.20 & 0.02 & 8.9 & - & - & - & - & - & - & Mo & 0.21 & 0.03 & 16.2 \\
\hline $\mathrm{Na}$ & 2400 & 200 & 8.3 & - & - & - & 2692 & 79 & 2.9 & 2580 & 126 & 4.9 & 2227 & 49 & 2.2 & - & - & - & - & - & - & - & - & - & $\mathrm{Na}$ & 2499 & 243 & 9.7 \\
\hline $\mathrm{Ni}$ & 0.67 & 0.08 & 11.9 & - & - & - & 0.92 & 0.24 & 26.6 & 0.72 & 0.03 & 4.7 & - & - & - & 0.97 & 0.19 & 19.1 & - & - & - & 0.67 & 0.12 & 18.1 & $\mathrm{Ni}$ & 0.82 & 0.15 & 18.0 \\
\hline $\mathbf{P b}$ & 0.086 & 0.007 & 8.1 & 0.094 & 0.008 & 8.1 & 0.082 & 0.036 & 43.6 & 0.084 & 0.001 & 1.7 & 0.077 & 0.010 & 12.4 & - & - & - & - & - & - & - & - & - & $\mathbf{P b}$ & 0.084 & 0.007 & 8.4 \\
\hline Sb & 0.23 & 0.04 & 17.4 & - & - & - & 0.30 & 0.15 & 49.3 & 0.25 & 0.005 & 1.9 & - & - & - & - & - & - & - & - & - & - & - & - & Sb & 0.27 & 0.04 & 13.5 \\
\hline $\mathrm{Sr}$ & 26.3 & 3.2 & 12.2 & 28.3 & 1.3 & 4.5 & 28.2 & 1.0 & 3.4 & 30.1 & 0.7 & 2.3 & 28.4 & 0.5 & 1.9 & 28.6 & 2.2 & 7.7 & 28.4 & 0.6 & 1.9 & 25.5 & 0.9 & 3.6 & $\mathrm{Sr}$ & 28.2 & 1.36 & 4.8 \\
\hline $\mathbf{U}$ & 0.05 & 0.003 & 6.0 & |0.0522* & 0.0003 & 0.6 & 0.046 & 0.003 & 6.7 & 0.045 & 0.002 & 3.4 & 0.050 & 0.002 & 4.6 & 0.055 & 0.006 & 10.5 & - & - & . & 0.043 & 0.012 & 27.4 & $\mathbf{U}$ & 0.05 & 0.00 & 10.0 \\
\hline $\mathbf{v}$ & 0.32 & 0.03 & 9.4 & 0.366 & 0.025 & 6.9 & 0.349 & 0.032 & 9.1 & 0.343 & 0.004 & 1.3 & - & - & - & 0.367 & 0.050 & 13.5 & - & - & - & 0.329 & 0.027 & 8.2 & v & 0.35 & 0.02 & 4.6 \\
\hline $\mathrm{Zn}$ & 0.93 & 0.1 & 10.8 & 1.09 & 0.10 & 8.7 & 1.42 & 0.41 & 29.0 & 0.93 & 0.03 & 3.4 & 1.20 & 0.08 & 6.6 & 1.59 & 0.29 & 18.3 & 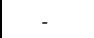 & . & - & - & - & 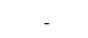 & $\mathrm{Zn}$ & 1.24 & 0.26 & 21.0 \\
\hline
\end{tabular}

$\mathrm{n}=$ number of results

sd : standard deviation

rsd : relative standard deviatio

$* n=3$

: no measurement available

italics : outside the certified confidence limits 
Table 4 : Average concentration values $\left(\right.$ ng. $\left.^{-1}\right)$, standard deviation and relative standard deviation of REEs in the river water standard SLRS-4.

\begin{tabular}{|c|c|c|c|c|c|c|c|c|c|c|c|c|c|c|c|c|c|c|c|}
\hline & \multicolumn{3}{|c|}{ Nancy on-line chromato $(n=16)$} & \multicolumn{3}{|c|}{ Toulouse direct $(n=27)$} & \multicolumn{3}{|c|}{ Toulouse desolvator $(\mathrm{n}=32)$} & \multicolumn{3}{|c|}{ Rennes direct $(\mathrm{n}=\mathbf{8 4})$} & \multicolumn{3}{|c|}{ IRD Bondy (n=15) } & \multicolumn{4}{|c|}{ COMPILATION } \\
\hline & average & sd & $\operatorname{rsd}(\%)$ & average & sd & $\operatorname{rsd}(\%)$ & average & sd & $\operatorname{rsd}(\%)$ & average & sd & $\operatorname{rsd}(\%)$ & average & sd & $\operatorname{rsd}(\%)$ & & average & sd & rsd $(\%)$ \\
\hline $\mathbf{L a}$ & 275.6 & 10.3 & 3.7 & 292.1 & 2.6 & 0.9 & 295.5 & 6.5 & 2.2 & 281.8 & 4.4 & 1.5 & 288.7 & 18.3 & 6.3 & La & 287 & 8 & 2.8 \\
\hline $\mathrm{Ce}$ & 340.5 & 20.1 & 5.9 & 363.0 & 4.9 & 1.4 & 371.5 & 7.2 & 1.9 & 357.9 & 4.3 & 1.2 & 368.4 & 21.8 & 5.9 & $\mathrm{Ce}$ & 360 & 12 & 3.4 \\
\hline Pr & 67.4 & 3.0 & 4.4 & 68.6 & 1.9 & 2.8 & 70.8 & 1.4 & 1.9 & 68.0 & 1.0 & 1.4 & 71.7 & 4.6 & 6.5 & Pr & 69.3 & 1.8 & 2.6 \\
\hline Nd & 255.1 & 12.8 & 5.0 & 287.8 & 9.4 & 3.3 & 280.4 & 6.1 & 2.2 & 262.5 & 2.7 & 1.0 & 259.3 & 13.7 & 5.3 & Nd & 269 & 14 & 5.3 \\
\hline Sm & 54.3 & 3.2 & 5.9 & 56.5 & 1.4 & 2.6 & 59.2 & 1.4 & 2.4 & 55.9 & 1.0 & 1.7 & 61.3 & 3.8 & 6.2 & Sm & 57.4 & 2.8 & 4.9 \\
\hline $\mathbf{E u}$ & 7.9 & 1.2 & 15.4 & 7.4 & 0.3 & 3.5 & 8.7 & 1.0 & 12.0 & 7.7 & 0.3 & 4.5 & 8.4 & 0.6 & 6.7 & $\mathbf{E u}$ & 8.0 & 0.6 & 6.9 \\
\hline Gd & 36.2 & 4.5 & 12.6 & 31.6 & 2.1 & 6.6 & 33.0 & 3.5 & 10.6 & 34.2 & 0.8 & 2.4 & 36.0 & 4.5 & 12.5 & Gd & 34.2 & 2.0 & 5.7 \\
\hline $\mathbf{T b}$ & 4.4 & 0.7 & 16.7 & 3.8 & 0.3 & 8.5 & 4.3 & 0.1 & 2.2 & 4.2 & 0.2 & 4.2 & 4.8 & 0.4 & 8.8 & $\mathbf{T b}$ & 4.3 & 0.4 & 8.4 \\
\hline Dy & 24.3 & 1.2 & 4.8 & 22.3 & 1.0 & 4.7 & 24.3 & 0.7 & 2.9 & 23.5 & 0.6 & 2.6 & 26.6 & 1.9 & 7.2 & Dy & 24.2 & 1.6 & 6.4 \\
\hline Но & 4.8 & 0.7 & 13.7 & 4.2 & 0.4 & 8.9 & 4.7 & 0.1 & 3.1 & 4.6 & 0.1 & 3.2 & 5.0 & 0.3 & 6.5 & Ho & 4.7 & 0.3 & 5.7 \\
\hline Er & 13.9 & 1.0 & 6.9 & 12.4 & 0.5 & 3.8 & 13.6 & 0.4 & 2.7 & 13.3 & 0.5 & 3.8 & 13.8 & 0.8 & 5.8 & $\mathbf{E r}$ & 13.4 & 0.6 & 4.5 \\
\hline $\mathbf{T m}$ & 1.7 & 0.1 & 8.0 & 1.5 & 0.2 & 13.3 & 1.8 & 0.1 & 4.2 & 1.9 & 0.2 & 8.6 & & & & Tm & 1.7 & 0.2 & 10.4 \\
\hline $\mathbf{Y b}$ & 11.5 & 0.8 & 7.3 & 12.0 & 1.0 & 8.3 & 12.2 & 0.5 & 3.8 & 11.8 & 0.4 & 3.5 & 12.4 & 0.7 & 6.0 & $\mathbf{Y b}$ & 12.0 & 0.4 & 3.2 \\
\hline$\underline{\mathbf{L u}}$ & 1.8 & 0.3 & 16.8 & 1.9 & 0.3 & 14.0 & 1.9 & 0.1 & 3.7 & 2.0 & 0.2 & 8.3 & 1.9 & 0.2 & 9.0 & Lu & 1.9 & 0.1 & 3.1 \\
\hline
\end{tabular}

$\mathrm{n}=$ number of results

sd : standard deviation

rsd : relative standard deviation 
Table 5 : Proposed mean concentration values $\left(\mu \mathrm{g} . \mathrm{I}^{-1}\right)$, number of measurements, standard deviation and relative standard deviation of uncertified elements in the river water standard SLRS-4.

\begin{tabular}{|c|c|c|c|c|c|c|c|c|c|c|c|c|c|c|c|c|c|c|c|c|c|c|c|c|c|c|c|c|c|c|c|c|c|}
\hline & \multicolumn{4}{|c|}{ Nancy direct } & \multicolumn{4}{|c|}{ Toulouse direct } & \multicolumn{4}{|c|}{ Toulouse desolvator } & \multicolumn{4}{|c|}{ Rennes } & \multicolumn{4}{|c|}{ IRD Bondy } & \multicolumn{4}{|c|}{ UPMC Paris } & \multicolumn{4}{|c|}{ La Rochelle } & \multicolumn{5}{|c|}{ COMPILATION } \\
\hline & $\mathrm{n}$ & average & sd & rsd (\%) & $\mathrm{n}$ & average & sd & rsd (\%) & $\mathrm{n}$ & average & sd & rsd (\%) & $\mathrm{n}$ & average & sd & rsd (\%) & $\mathrm{n}$ & average & sd & $\operatorname{rsd}(\%)$ & $\mathrm{n}$ & average & sd & rsd (\%) & $\mathrm{n}$ & average & sd & rsd (\%) & Element & $\mathrm{n}$ & average & sd & $\operatorname{rsd}(\%)$ \\
\hline $\mathrm{Ag}$ & & & & & 14 & 0.035 & 0.005 & 14 & & & & & & & & & & & & & & & & & & & & & $\mathrm{Ag}$ & 14 & 0.035 & 0.005 & 14 \\
\hline B & 4 & 6.05 & 0.09 & 1 & 6 & 6.11 & 0.22 & 4 & & & & & & & & & & & & & 3 & 5.70 & 0.45 & 8 & & & & & B & 13 & 5.95 & 0.22 & 4 \\
\hline $\mathrm{Br}$ & & & & & 6 & 48 & 2 & 5 & & & & & & & & & & & & & & & & & & & & & $\mathrm{Br}$ & 6 & 47.8 & 2.0 & 4 \\
\hline Cs & & & & & 28 & 0.008 & 0.002 & 23 & 16 & 0.009 & 0.002 & 23 & & & & & & & & & & & & & & & & & Cs & 44 & 0.009 & 0.001 & 11 \\
\hline $\mathrm{Ga}$ & & & & & 29 & 0.012 & 0.002 & 19 & 16 & 0.012 & 0.001 & 9 & & & & & & & & & & & & & & & & & Ga & 45 & 0.0119 & 0.0004 & 3 \\
\hline Ge & & & & & 28 & 0.012 & 0.004 & 33 & 16 & 0.008 & 0.002 & 26 & & & & & & & & & & & & & & & & & Ge & 44 & 0.010 & 0.003 & 27 \\
\hline $\mathbf{L i}$ & 11 & 0.444 & 0.013 & 3 & 31 & 0.515 & 0.117 & 23 & 6 & 0.615 & 0.027 & 4 & & & & & 6 & 0.524 & 0.066 & 13 & 11 & 0.610 & 0.015 & 2 & 15 & 0.504 & 0.026 & 5 & $\mathbf{L i}$ & 80 & 0.54 & 0.07 & 12 \\
\hline Pd & & & & & 21 & 0.021 & 0.006 & 28 & & & & & & & & & & & & & & & & & & & & & Pd & 21 & 0.021 & 0.006 & 29 \\
\hline $\mathbf{R b}$ & 11 & 1.57 & 0.04 & 2 & 27 & 1.57 & 0.07 & 4 & 16 & 1.58 & 0.02 & 1 & 84 & 1.56 & 0.04 & 3 & 6 & 1.43 & 0.16 & 11 & 15 & 1.49 & 0.09 & 6 & 15 & 1.53 & 0.10 & 6 & $\mathbf{R b}$ & 178 & 1.53 & 0.05 & 3 \\
\hline $\mathbf{R} \mathbf{b}^{*}$ & & & & & & & & & & & & & 4 & 1.54 & 0.01 & 1 & & & & & & & & & & & & & & & & & \\
\hline $\mathrm{Se}$ & & & & & & & & & 16 & 0.23 & 0.03 & 13 & & & & & & & & & & & & & & & & & Se & 16 & 0.23 & 0.03 & 13 \\
\hline $\mathbf{S i}$ & & & & & 21 & $1616^{* * * *}$ & 377 & 23 & 16 & $1443^{* * *}$ & 266 & 18 & 84 & 1820 & 36 & 2 & & & & & & & & & & & & & $\mathrm{Si}$ & 99 & 1864 & 48 & 3 \\
\hline $\mathrm{Si}^{* * *}$ & 6 & 1916 & 26 & 1 & & & & & & & & & 9 & 1857 & 17 & 1 & & & & & & & & & & & & & & & & & \\
\hline Th & & & & & 27 & 0.018 & 0.003 & 18 & 32 & 0.018 & 0.003 & 20 & 84 & 0.014 & 0.002 & 14 & 2 & 0.021 & 0.001 & 5 & & & & & & & & & Th & 145 & 0.018 & 0.003 & 16 \\
\hline $\mathbf{T i}$ & & & & & 31 & 1.56 & 0.14 & 9 & 16 & 1.43 & 0.06 & 4 & & & & & 7 & 1.40 & 0.09 & 6 & & & & & & & & & $\mathrm{Ti}$ & 54 & 1.46 & 0.08 & 6 \\
\hline W & & & & & 2 & 0.013 & 0.001 & 4 & & & & & & & & & & & & & & & & & & & & & w & 2 & 0.0133 & 0.0010 & 7 \\
\hline $\mathbf{Y}$ & & & & & 31 & 0.139 & 0.005 & 3 & 16 & 0.144 & 0.003 & 2 & & & & & 4 & 0.155 & 0.019 & 12 & & & & & & & & & $\mathbf{Y}$ & 51 & 0.146 & 0.008 & 5 \\
\hline $\mathrm{Zr}$ & & & & & 27 & 0.13 & 0.02 & 16 & 32 & 0.11 & 0.01 & 5 & & & & & & & & & & & & & & & & & $\mathrm{Zr}$ & 59 & 0.12 & 0.015 & 13 \\
\hline
\end{tabular}

$\mathrm{n}=$ number of results $\quad$ sd : standard deviation $\quad$ rsd : relative standard deviation $\quad$ italics : compilation value from less than 3 different laboratories

$*:$ Rb value obtained by Isotope Dilution-TIMS $\quad$ **: Si values obtained by spectrophotometry $\quad * * *:$ exluded from the compilation value 